\title{
Selenium and Vitamin E Status Correlated with Myopathies of Horses Reared in Farms in the Czech Republic
}

\author{
E. LUDVÍKOVÁ ${ }^{1}$, P. JAHN ${ }^{1}$, L. PAVLATA ${ }^{2}$, M. VYSKOČIL ${ }^{3}$ \\ ${ }^{1}$ Equine Clinic, ${ }^{2}$ Clinic of Diseases of Ruminants, ${ }^{3}$ Department of Genetics, Faculty of Veterinary Medicine, \\ University of Veterinary and Pharmaceutical Sciences Brno, Czech Republic \\ Received December 12, 2004 \\ Accepted June 6, 2005
}

\begin{abstract}
Ludvíková E., P. Jahn, L. Pavlata, M. Vyskočil: Selenium and Vitamin E Status Correlated with Myopathies of Horses Reared in Farms in the Czech Republic. Acta Vet. Brno 2005, 74: 377-384.

The objective of the study was to compare selenium and vitamin E status in equine farms with and without occurrence of myopathies in order to evaluate the role of lack of these substances in the aetiology of myopathies in horses in the Czech Republic. Concentrations of selenium (in 136 horses) and vitamin $\mathrm{E}$ (in 131 horses) and glutathione peroxidase (GSH-Px) activities (in 136 horses) were measured in horses from farms with the occurrence of myopathies (group M including 46 horses from 10 farms) and in horses from farms without occurrence of myopathies (group Hincluding 90 horses from 22 farms). Significantly lower concentrations of selenium $\left(43.09 \pm 36.84 \mu \mathrm{g} \cdot \mathrm{l}^{-1} ; p<0.001\right)$, vitamin E $\left(9.55 \pm 9.29 \mu \mathrm{mol} \cdot \mathrm{l}^{-1}\right.$; $p<0.01)$ and GSH-Px activities $\left(153.38 \pm 177.28 \mu \mathrm{kat} \cdot \mathrm{l}^{-1} ; p<0.001\right)$ were found in horses from the farms with the occurrence of myopathies when compared to those without the occurrence of myopathies (Se $117.35 \pm 52.10 \mu \mathrm{g} \cdot \mathrm{l}^{-1}$; vitamin E $10.75 \pm 4.34 \mu \mathrm{mol} \cdot \mathrm{l}^{-1}$; GSH-Px $\left.397.41 \pm 242.15 \mu \mathrm{kat} \cdot \mathrm{l}^{-1}\right)$. The diagnosis of nutritional myodegeneration (white muscle disease, WMD) was established in six horses with myopathy. The aetiology of myopathy in the other four affected horses was probably different. Evaluating all examined horses, insufficient whole blood selenium and serum vitamin E concentrations were found in $42 \%$ and $96 \%$ of horses, respectively. Poor saturation with selenium and vitamin Eare important factors in the aetiology of WMD in horses in the Czech Republic. Apart from WMD, horses in the Czech Republic may be affected by some other myopathies.
\end{abstract}

Glutathione peroxidase, nutritional myodegeneration, white muscle disease, tocopherol, creatine kinase, aspartate aminotransferase

Myopathies in horses represent a group of diseases which great attention has been paid to recently. The classification of myopathies regarding their clinical course runs against the fact that one disorder may have variable clinical signs while myopathies of different aetiology may have similar clinical signs. The clinical examination and biochemistry is necessary for the diagnosis of myopathy. However, histochemical analysis of a muscle biopsy is required for the diagnosis of the type of myopathy (MacLeay 2004). Following disorders of skeletal muscles have been recognised in horses:

- Nutritional myodegeneration (white muscle disease, WMD) is a disorder caused by selenium and vitamin E deficiency. The condition occurs more often in foals (Löfstedt 1997; Harris 1998; Valberg 2002). It is less common in adult horses and affects predominantly masticatory muscles in them (Step et al. 1991). Diagnosis of WMD relies on determining the activities of serum creatine kinase (CK), aspartate aminotransferase (AST) and whole blood glutathione peroxidase (GSH-Px) activity and selenium concentration (Löfstedt 1997; Harris 1998; Valberg 2002).

Direct correlation between the selenium concentration and the activity of glutathione peroxidase in whole blood in horses was found (Roneus and Lindholm 1983; Blackmore et al. 1982; Ludvíková et al. 2005). The geographic distribution of the disorder is restricted to areas of low selenium concentrations in the soil. 
- Polysaccharide storage myopathy (PSSM) is a disorder that was found in Quarter Horse, Draft horse breeds, Warmbloods and related breeds. It is an inherited disorder probably of autosomal recessive heredity (De La Corte et al. 2002) associated with abnormal storage of glycogen and its pathological form in muscle fibres (Valberg 2002; Valentine et al. 2001). Diagnosis is based on muscle biopsy from $m$. semitendinosus, m. semimembranosus or $m$. gluteus medius. PSSM is confirmed by evidence of PAS-positive (periodic acid-Shiff) and amylase resistant inclusions in muscle fibres (Valberg et al. 1997).

- Exertional myopathies (exertional rhabdomyolysis, ER) occur in Thoroughbreds. According to some authors ER has similar aetiology as PSSM (Valentine et al. 1997, Valentine et al. 1998). Contrary to this opinion, MacLeay et al. (1999) and Lentz et al. (1999) assume that the disorder is caused by defective muscle contractions and forms nosologic entity recurrent exertional rhabdomyolysis (RER), probably of autosomal dominant heredity (Mac L eay et al. 1999). The increased number of centrally located nuclei without the presence of inclusions of abnormal polysaccharides was found in muscle biopsies from RER affected horses (MacLeay et al. 1999).

Myopathies due to selenium and vitamin E deficiency have been recognised in many animal species in the Czech Republic (Kursa 1969; Pavlata et al. 2001). There are only sporadic reports on these problems in horses (Kursa et al. 1970).

The objective of our study was:

1. To compare differences in selenium and vitamin E status in horses from equine farms with and without occurrence of myopathies.

2. On the basis of selenium (Se) and vitamin E concentrations and glutathione peroxidase (GSH-Px) activities in patients of the Equine Clinic (University of Veterinary and Pharmaceutical Sciences Brno) with myopathy to distinguish between WMD and myopathy of different aetiology.

\section{Materials and Methods}

The study continues and extends the results of previous study on selenium status of horses in the Czech Republic (Ludvíková et al. 2005). In this paper the group of horses examined was analysed in a greater detail with respect to the relation of selenium and vitamin E status and the occurrence of myopathies.

Characteristics of horses examined

A total of 136 horses of different breeds were included into the study (20 Thoroughbreds, 59 Czech Warmbloods, 26 Standardbreds, 2 Welsh ponies, 2 Shetland ponies, 1 German riding pony, 10 Shagya Arabs, 1 Anglo-Arab, 8 Friesian horses, 4 Belgian horses, 1 Noric horse, 1 Hucul, 1 Haflinger horse). There were 66 mares, 23 stallions and 47 geldings with the age ranging from one month to 23 years in this group of horses. The use of these horses was quite variable ranging from foal rearing to racehorses, dressage, show jumping, pleasure and breeding horses. Ten horses of this group were on the basis of clinical signs (stiffness, muscle swelling, inability to move, recumbency, dysphagia and myoglobinuria) and blood biochemistry findings (increased CK and AST activity) diagnosed with a myopathy. Table 1 gives the characteristics of the horses in a greater detail.

The horses came from 32 farms in the Czech Republic (Table 2). These farms were divided into two groups considering the occurrence of myopathies:

1. Farms with clinically healthy horses and no cases of myopathies - group H (22 farms amounting to the total of 90 horses).

2. Farms with clinically manifested myopathies - group M (10 farms amounting 46 horses). Even when the myopathy was confirmed in one horse, all horses of the farm were included into this group.

Diagnosis of the nutritional myodegeneration in horses of the group $\mathrm{M}$ was confirmed on the basis of the above-mentioned clinical signs, increased CK and AST activities and decreased selenium concentration (lower than $75 \mu \mathrm{g} \cdot \mathrm{l}^{-1}$ ) and GSH-Px activity (lower than $200 \mu \mathrm{kat} \cdot \mathrm{l}^{-1}$ ) (Ludvík ová et al. 2005).

Sample collection and laboratory analyses

Samples were collected from July 2002 to June 2003. A total of 136 blood samples were collected from vena jugularis. Each sample was then divided into two tubes:

1. Whole blood collected into a tube with Li heparin was used to determine the selenium concentration and the activity of GSH-Px. Samples were frozen within $12 \mathrm{~h}$ of collection and kept at $-20^{\circ} \mathrm{C}$ until processing.

2. Serum obtained after blood coagulation was used to analyse the vitamin E concentration. It was kept in a refrigerator until the time of laboratory processing. 


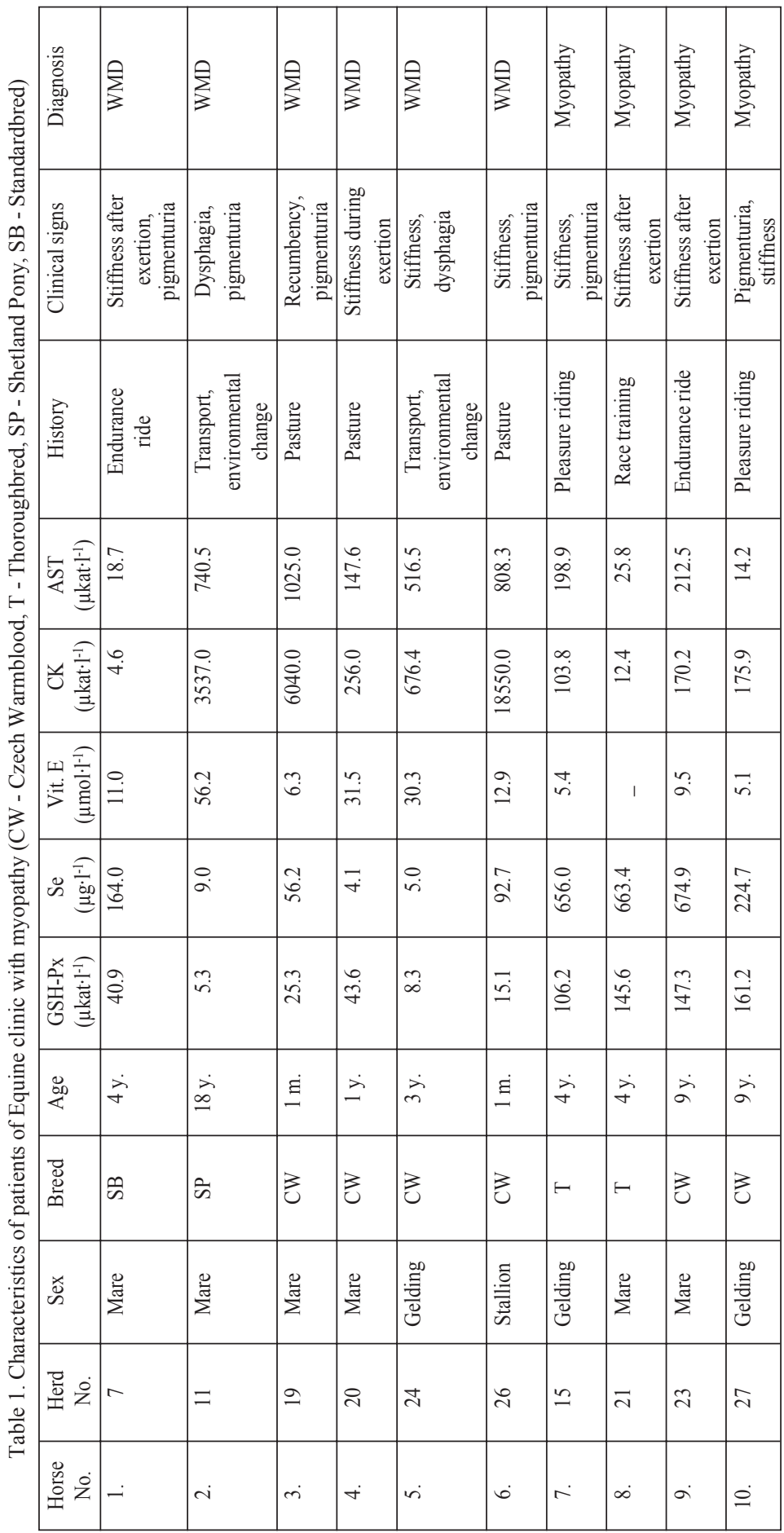

The activity of GSH-Px and selenium concentration in whole blood was measured in all horses. The serum vitamin E concentration was determined in 131 horses. All laboratory analyses were performed at the Department of Laboratory Diagnostics of the Clinic of Diseases of Ruminants (University of Veterinary and Pharmaceutical Sciences Brno).

For purposes of selenium determination the samples were at first mineralized in a closed system using the microwave digestion technique together with $\mathrm{HNO}_{3}$ and $\mathrm{H}_{2} \mathrm{O}_{2}$ employing the MILESTONE unit (MLS - 1200 model). The nitric acid was then evaporated and the mineral matter turned into a water solution with $20 \% \mathrm{HCl}$ added. Selenium was measured in this solution using the UNICAM 939 AA spectrometer employing the hydride technique of AAS. The selenium concentration in whole blood was expressed in $\mu \mathrm{g} \cdot \mathrm{l}^{-1}$. The same sample of whole blood was used to determine the activity of GSH-Px. It was measured using the method by Paglia and Valentine (1967) employing the Ransel set supplied by the Randox company and the COBAS MIRA automatic analyser. The resulting activities of GSH-Px are expressed as $\mu \mathrm{kat} \cdot \mathrm{l}^{-1}$ of whole blood.

The vitamin E concentration was determined by a fluorometric method using the fluorescence spectrophotometer 204Perkin-Elmer (Thompson etal.1971; Bouda et al. 1980). 
Methods of statistical evaluation

Data were evaluated using programs Microsoft EXCEL and KyPlot computing basic statistics of selenium concentration, GSH-Px activity and serum vitamin E concentration. Groups of horses with and without myopathies were compared by the non-parametric Wilcoxon test for two-paired samples.

\section{Results}

Mean concentrations of selenium, activities of GSH-Px and the concentration of vitamin $\mathrm{E}$ in horses of each farm is presented in Table 2.

The mean selenium concentration and GSH-Px activity were significantly higher $(p<$ 0.001 ) in group $\mathrm{H}$ than in group $\mathrm{M}$ (Table 3).

The mean vitamin E concentration was also significantly higher $(p<0.01)$ in equine farms without the occurrence of myopathies (Table 4).

The nutritional myodegeneration was diagnosed on the basis of clinical signs, elevated $\mathrm{CK}$ and AST activities and low concentrations of selenium and GSH-Px activities in horses No. 1, 2, 3, 4, 5 and 6 .

\section{Discussion}

The difference in the selenium concentration and GSH-Px activity between both groups $\mathrm{H}$ and $\mathrm{M}$ provides evidence for selenium deficiency in the group $\mathrm{M}$ resulting in the occurrence of myopathies in some equine farms in the Czech Republic. Values of the standard deviation of the selenium concentration in the group M suggest that this group is rather variable and includes horse farms with sufficient as well as insufficient selenium status. According to this finding, not only myopathies due to selenium deficiency but also of other types occur in horses in the Czech Republic (Blackmore et al. 1982; Valentine et al. 1998).

Valentine (2003) considers the determination of concentrations of selenium and vitamin $\mathrm{E}$ as ancillary diagnostic criterium for distinguishing PSSM from WMD. Sufficient concentration of selenium and the GSH-Px activity in a myopathic horse supply evidence that the horse is not affected by WMD. In horses with insufficient selenium concentration in blood, however, it is not possible to distinguish WMD from myopathies of other aetiology. History and the clinical course may have some importance in the differential diagnostics of the disease. PSSM is only occasionally found in horses younger three years, while, on the other hand, WMD occurs in foals, in particular (Löfstedt 1997; Harris 1998; Valberg 2002). RER is most frequent in horses in race training. Prognosis of WMD is dubious, while in PSSM and RER it is better. There are, however, frequent recurrent attacks of the disease both in PSSM and RER. Histological and histochemical examinations of muscle biopsy are necessary for the final diagnosis (Valentine 2003).

WMD is the main clinical manifestation of selenium deficiency in horses. Occurrence of WMD in farm animals is bound to selenium deficient soils in some regions of the Czech Republic (Pavlata et al. 2002). Ludvíková et al. (2005) found in as many as 44\% of 159 horses inadequate selenium concentrations and low activities of GSH-Px in whole blood (the selenium concentration and the activity of GSH-Px less than $75 \mu \mathrm{g} \cdot \mathrm{l}^{-1}$ and $200 \mu \mathrm{kat} \cdot \mathrm{l}^{-1}$, respectively). These data provide evidence for the finding that selenium deficiency resulting in the risk of WMD is rather common in horses in the Czech Republic.

It has been reported that foals younger than one year prevail among horses affected by WMD (Löfstedt 1997; Harris 1998; Valberg 2002). Contrary to this, we found a higher percentage of adult horses (No. 1, 2 and 5). Horses No. 2 and 5 showed the same clinical sign - dysphagia. Both of them were transported to a new farm and changed environmental conditions shortly before the onset of clinical signs. The horse No. 1 was deficient in 
Table 2. Characteristics of equine farms including the mean selenium and vitamin E concentrations and the GSH-Px activities ( $\mathrm{H}$ - horses from farms without the occurrence of myopathies, $\mathrm{M}$ - horses from farms with the occurrence of clinical myopathies)

\begin{tabular}{|c|c|c|c|c|c|c|c|}
\hline $\begin{array}{c}\text { Farm } \\
\text { number }\end{array}$ & Region & Locality & $\mathrm{n}$ & Group & $\begin{array}{c}\mathrm{Se} \\
\left(\mu \mathrm{g} \cdot \mathrm{l}^{-1}\right)\end{array}$ & $\begin{array}{l}\text { GSH-Px } \\
\left(\mu \mathrm{kat} \cdot \cdot^{-1}\right)\end{array}$ & $\begin{array}{c}\text { Vit. E } \\
\left(\mu \mathrm{mol} \cdot \cdot^{-1}\right)\end{array}$ \\
\hline 1 & \multirow[t]{4}{*}{ Plzeňský } & Sušice & 6 & $\mathrm{H}$ & 28.55 & 54.27 & 11.31 \\
\hline 2 & & Sušice & 6 & $\mathrm{H}$ & 53.61 & 72.22 & 10.29 \\
\hline 3 & & Sušice & 7 & $\mathrm{H}$ & 67.78 & 114.62 & 10.61 \\
\hline 4 & & Sušice & 3 & $\mathrm{H}$ & 74.55 & 166.20 & 13.59 \\
\hline 5 & Liberecký & Jablonec n. N. & 1 & $\mathrm{H}$ & 174.60 & 710.90 & 10.25 \\
\hline 6 & \multirow[t]{8}{*}{ Středočeský } & Poděbrady & 12 & $\mathrm{H}$ & 109.33 & 281.71 & 10.09 \\
\hline 7 & & Sedlčany & 12 & $\mathrm{M}$ & 32.95 & 120.75 & 11.50 \\
\hline 8 & & Benešov & 11 & $\mathrm{H}$ & 117.24 & 287.66 & 9.06 \\
\hline 9 & & Benešov & 6 & $\mathrm{H}$ & 193.82 & 710.32 & 15.07 \\
\hline 10 & & Benešov & 1 & $\mathrm{H}$ & 88.52 & 486.30 & - \\
\hline 11 & & Benešov & 1 & $\mathrm{M}$ & 5.27 & 9.02 & 56.50 \\
\hline 12 & & Kutná Hora & 1 & $\mathrm{H}$ & 188.70 & 550.60 & 9.00 \\
\hline 13 & & Tochovice & 1 & $\mathrm{H}$ & 115.10 & 569.90 & 11.00 \\
\hline 14 & Praha & Praha & 1 & $\mathrm{H}$ & 48.92 & 121.00 & 8.28 \\
\hline 15 & Jihočeský & C. Krumlov & 5 & $\mathrm{M}$ & 88.82 & 490.76 & 6.40 \\
\hline 16 & \multirow[t]{3}{*}{ Pardubický } & Pardubice & 8 & $\mathrm{H}$ & 109.36 & 513.90 & 19.46 \\
\hline 17 & & Pardubice & 1 & $\mathrm{H}$ & 133.30 & 775.30 & 9.75 \\
\hline 18 & & Pardubice & 1 & $\mathrm{H}$ & 125.50 & 765.50 & 8.25 \\
\hline 19 & Vysočina & Humpolec & 6 & M & 26.97 & 69.10 & 4.48 \\
\hline 20 & \multirow[t]{4}{*}{ Olomoucký } & Prostějov & 1 & $\mathrm{M}$ & 4.10 & 43.63 & 31.50 \\
\hline 21 & & Prostějov & 1 & $\mathrm{M}$ & 145.60 & 663.40 & - \\
\hline 22 & & Prostějov & 1 & $\mathrm{H}$ & 73.97 & 450.60 & 7.25 \\
\hline 23 & & Zábřeh na M. & 1 & M & 147.30 & 674.90 & 9.51 \\
\hline 24 & \multirow[t]{8}{*}{ Jihomoravský } & Brno & 1 & $\mathrm{M}$ & 8.30 & 5.00 & 30.25 \\
\hline 25 & & Brno & 4 & $\mathrm{H}$ & 173.00 & 550.95 & 5.81 \\
\hline 26 & & Brno & 1 & $\mathrm{M}$ & 17.81 & 72.87 & 6.59 \\
\hline 27 & & Vyškov & 12 & M & 69.54 & 187.51 & 5.37 \\
\hline 28 & & Břeclav & 15 & $\mathrm{H}$ & 161.11 & 599.19 & 8.03 \\
\hline 29 & & Břeclav & 1 & $\mathrm{H}$ & 133.40 & 767.50 & 13.13 \\
\hline 30 & & Hodonín & 1 & $\mathrm{H}$ & 141.90 & 710.10 & - \\
\hline 31 & & Hodonín & 1 & $\mathrm{H}$ & 117.40 & 747.80 & - \\
\hline 32 & Zlínský & Valaš. Klobouky & 1 & $\mathrm{H}$ & 146.10 & 396.90 & - \\
\hline
\end{tabular}

Table 3. Basic statistics of selenium concentrations and the whole blood GSH-Px activities of horses from equine farms without $(\mathrm{H})$ and with $(\mathrm{M})$ occurrence of myopathies $(\mathrm{n}=136)$

\begin{tabular}{|c|c|c|c|c|}
\hline & $\begin{array}{c}\mathrm{H}-\mathrm{Se} \\
\left(\mu \mathrm{g} \cdot \mathrm{l}^{-1}\right)\end{array}$ & $\begin{array}{c}\mathrm{M}-\mathrm{Se} \\
\left(\mu \mathrm{g} \cdot \mathrm{l}^{-1}\right)\end{array}$ & $\begin{array}{c}\mathrm{H}-\mathrm{GSH}-\mathrm{Px} \\
\left(\mu \mathrm{kat} \cdot \mathrm{l}^{-1}\right)\end{array}$ & $\begin{array}{c}\mathrm{M}-\mathrm{GSH}-\mathrm{Px} \\
\left(\mu \mathrm{kat} \cdot \mathrm{l}^{-1}\right)\end{array}$ \\
\hline Number of horses & 90 & 46 & 90 & 46 \\
\hline Mean & 117.35 & 43.09 & 397.41 & 153.38 \\
\hline Standard deviation & 52.10 & 36.84 & 242.15 & 177.28 \\
\hline Median & 120.21 & 30.20 & 396.90 & 93.10 \\
\hline Minimum & 8.28 & 5.27 & 29.90 & 737.00 \\
\hline Maximum & 238.10 & 161.20 & 952.00 & $p<0.001$ \\
\hline $\begin{array}{c}\text { Statistical } \\
\text { significance }\end{array}$ & \multicolumn{2}{|c|}{} \\
\hline
\end{tabular}


Table 4. Basic statistics of the serum vitamin E concentrations in horses from equine farms without $(\mathrm{H})$ and with $(\mathrm{M})$ occurrence of myopathies $(\mathrm{n}=131)$

\begin{tabular}{|c|c|c|}
\hline & $\mathrm{H}-\operatorname{vitamin} \mathrm{E}\left(\mu \mathrm{mol} \cdot \mathrm{r}^{-1}\right)$ & $\mathrm{M}$ - vitamin $\mathrm{E}\left(\mu \mathrm{mol} \cdot \mathrm{r}^{-1}\right)$ \\
\hline Number of horses & 86 & 45 \\
\hline Mean & 10.75 & 9.55 \\
\hline Standard deviation & 4.34 & 9.29 \\
\hline Median & 9.88 & 6.25 \\
\hline Minimum & 4.13 & 3.38 \\
\hline Maximum & 33.13 & 56.50 \\
\hline Statistical significance & \multicolumn{2}{|c|}{$p<0.001$} \\
\hline
\end{tabular}

selenium, but had different history (onset of clinical signs during an endurance ride), clinical signs (stiffness and pigmenturia without dysphagia) and the clinical course (no progress of clinical signs and recovery within two days) in comparison with horses No. 2 and 5. A muscle biopsy and histochemistry of the sample collected would have been necessary for a definitive diagnosis in this case.

The onset of nutritional myodegeneration in adult horses probably requires some stress factors such as the transport, change of environmental conditions or exertion. As there was no history of stress in the affected foals (horses No. 3, 4 and 6), it is our opinion that the selenium deficiency is sufficient enough to cause the disease. The role of stress in the pathogenesis of nutritional myodegeneration has also been reported by Caple et al. (1978), Roneus and Lindholm (1983), Löfstedt (1997) and Harris (1998).

Horses No. 1, 7, 8, 9 and 10 had all some kind of exertion in history (Table 1), which resulted in the onset of clinical signs of myopathy (stiffness and swelling of muscles, reluctance to move and myoglobinuria in some cases). There were no signs of dysphagia in these horses - a frequent manifestation of WMD in adults. The horse No. 9 had recurrent episodes of myopathy following endurance rides or training in history. Frequent and recurrent bouts of the disease following exertion are characteristic of ER, in particular. Horses No. 7, 8, 9 and 10 had adequate levels of selenium.

From results on the vitamin E concentration it is clear that the status of this vitamin in horses is quite variable ranging from 3.38 to $56.50 \mu \mathrm{mol} \cdot \mathrm{l}^{-1}$. The difference between both groups $\mathrm{H}$ and $\mathrm{M}$ in the vitamin $\mathrm{E}$ concentration is highly significant. In the majority of horses (96\%), however, concentrations lower than the recommended minimum of $23.2 \mu \mathrm{mol} \cdot \mathrm{r}^{-1}$ (Malikides et al. 2000) were found. Regarding this fact, most equine farms were of inadequate vitamin $\mathrm{E}$ status. It could be caused by poor quality of hay losing up to $80 \%$ of vitamin E during drying and storage (Weis s 1998). The main source of vitamin $\mathrm{E}$ for horses is feed intake on pasture (fresh fodder crops) (McKenzie et al. 2003). Frequent lack of this diet component may contribute to this status, in particular. Grain-based feeds are not an important source of vitamin $\mathrm{E}$, the content of which decreases as a result of processing (rolling and crushing). Though low levels of vitamin E only (without selenium deficiency) have not been reportedly associated with WMD but its supplementation is considered useful (Löfstedt 1997).

It can be concluded that the highly significant difference between groups $\mathrm{H}$ and $\mathrm{M}$ in concentrations of selenium and vitamin E as well as the activity of GSH-Px provides evidence for the occurrence of myopathies due to their deficiency in horses in the Czech Republic. The presence of some equine farms not deficient in selenium or vitamin $\mathrm{E}$ in the group $\mathrm{M}$ confirms the occurrence of myopathies independent of the selenium and vitamin E status. The diagnostic protocols to examine myopathic horses thus have to include the determination of selenium and vitamin E concentrations, the GSH-Px activity as well as muscle biopsy. 
As the deficiency of selenium and vitamin E predisposes horses for WMD, the status of these substances should be paid proper attention to as a part of preventive diagnostics.

\section{Stav zásobení selenem a vitaminem $\mathrm{E}$ v chovech koní České republiky s výskytem a bez výskytu myopatií}

Cílem práce bylo porovnat stav zásobení selenem a vitaminem E v chovech koní s výskytem a bez výskytu myopatií a posoudit tak vliv zásobení selenem a vitaminem E na vznik myopatií u koní v České republice. U koní pocházejících z chovů s výskytem myopatií - skupina M (46 koní z 10 chovů) i bez výskytu myopatií - skupina H (90 koní z 22 chovů) byla stanovena koncentrace selenu (Se), aktivita glutathionperoxidázy (GSH-Px) a koncentrace vitaminu E. V chovech koní s výskytem myopatií byla zjištěna průkazně nižší koncentrace selenu $\left(43,09 \pm 36,84 \mu \mathrm{g} \cdot \mathrm{l}^{-1} ; p<0,001\right)$, aktivita GSH-Px $\left(153,38 \pm 177,28 \mu \mathrm{kat} \cdot \mathrm{l}^{-1} ; p<0,001\right)$ i koncentrace vitaminu $\mathrm{E}\left(9,55 \pm 9,29 \mu \mathrm{mol} \cdot \mathrm{l}^{-1}\right.$; $p<0,01)$ v porovnání s chovy koní, kde se myopatie nevyskytovaly (Se 117,35 $\pm 52,10$ $\mu \mathrm{g} \cdot \mathrm{l}^{-1}$; GSH-Px 397,41 $\pm 242,15 \mu \mathrm{kat} \cdot \mathrm{l}^{-1}$; vit. E 10,75 \pm 4,34 $\mu \mathrm{mol} \cdot \mathrm{l}^{-1}$ ). U šesti koní s myopatií byla stanovena diagnóza nutriční myodegenerace (WMD), u dalších čtyř koní se jednalo pravděpodobně o myopatii jiné etiologie. Vyhodnocením celého souboru koní byla u 42 \% vyšetřených koní zjištěna snížená koncentrace selenu v plné krvi a u 96 \% koní snížená sérová koncentrace vitaminu E. Bylo potvrzeno, že nízká saturace selenem a vitaminem E jsou významné faktory podílející se na vzniku WMD u koní v České republice. Kromě WMD se v našich chovech koní vyskytují i myopatie jiné etiologie.

\section{Acknowledgement}

The work was supported by the Ministry of Education, Youth and Sports of the Czech Republic (Grant No.161700002 and partly MSM 6215712403).

\section{References}

BLACKMORE DJ, CAMPBELL C, DANT C, HOLDEN JE, KENT JE 1982: Selenium status of thoroughbreds in the United Kingdom. Equine Vet J 14: 139-143

BOUDA J, JAGOŠ P, DVOŘÁK V 1980: Fluorometric determination of vitamins A and E in blood plasma, colostrum and the liver of cattle (in Czech). Čs Fysiol 29: 351

CAPLE IW, EDWARDS SJA, FORSYTH WM, WHITELEY P, SELTH RH, FULTON LJ 1978: Blood glutathione peroxidase activity in horses in relation to muscular dystrophy and selenium nutrition. Aust Vet $\mathrm{J}$ 54: $57-60$

DE LA CORTE FD, VALBERG S, MACLEAY JM, MICKELSON JR 2002: Developmental onset of polysaccharide storage myopathy in 4 Quarter Horse foals. J Vet Intern Med 16: 581-587

HARRIS AP 1998: Musculoskeletal Disease. In: REED SM, BAYLY WM (Ed).: Equine internal medicine. W. B. Saunders Company, St. Louis, pp. 371-426

KURSA J 1969: Nutriční svalová degenerace u mladého skotu v distriktu Šumavy. Vet Med (Praha) 14: $549-559$

KURSA J, KLEIN Z, LAVIČKA M 1970: Generalizovaná forma svalové degenerace u hř́iběte. Veterinářství 20: 540-541

LENTZ LR, VALBERG SJ, BALOG EM, MICKELSON JR, GALLANT EM 1999: Abnormal regulation of muscle contraction in horses with recurrent exertional rhabdomyolysis. Am J Vet Res 60: 992-999

LÖFSTEDT J 1997: White muscle disease of foals. Veterinary Clinics of North America: Equine Practice 13: $169-185$

LUDVÍKOVÁ E, PAVLATA L, VYSKOČIL M, JAHN P 2005: Selenium status of horses in the Czech Republic. Acta Vet Brno 74: 369-375

MACLEAY JM 2004: Diseases of the musculoskeletal system. In: REED SM, BAYLY WM, SELLON DC (Eds): Equine internal medicine, W. B. Saunders Company, St. Louis, pp. 461- 522

MACLEAY JM, SORUM SA, VALBERG SJ, MARSH WE, SORUM MD 1999: Epidemiologic analysis of factors influencing exertional rhabdomyolysis in Thoroughbreds. Am J Vet Res 60: 1562-1566

MALIKIDES N, HODGSON DR, ROSE RJ 2000: Neurology. In: ROSE RJ, HODGSON DR (Eds): Manual of equine practice, W. B. Saunders Company, St. Louis, pp. 503-575

MCKENZIE EC, VALBERG SJ, PAGAN JD 2003: Nutritional management of exertional rhabdomyolysis. In: ROBINSON NE (Ed): Current therapy in equine medicine, W. B. Saunders Company, St. Louis, pp. 727-734 
PAGLIA DE, VALENTINE WN 1967: Studies on the quantitative and qualitative characterisation of erythrocyte gluthatione peroxidase. J Lab Clin Med 70: 158-169

PAVLATA L, PECHOVÁ A, ILLEK J 2001: Muscular dystrophy in dairy cows following a change in housing technology. Acta Vet Brno 70: 269-275

PAVLATA L, ILLEK J, PECHOVÁ A, MATĚJÍČEK M 2002: Selenium status in cattle in the Czech Republic. Acta Vet Brno 71: 3-8

RONEUS BO, LINDHOLM A 1983: Glutathione peroxidase activity in the blood of healthy horses given different selenium supplementation. Nord Vet-Med 35: 337-345

STEP DL, DIVERS TJ, COOPER B 1991: Severe masseter myonecrosis in a horse. JAVMA 198: 117

THOMPSON JN, ERDODY P, BRIEN R, MURRAY TK 1971: Fluorometric determination of vitamin A in human blood and liver. Biochem Med 5: 67-89

VALBERG SJ 2002: A review of the diagnosis and treatment of rhabdomyolysis in foals. AAEP Proceedings 48: 117-121

VALBERG SJ, MACLEAY JM, MICKELSON JR 1997: Exertional rhabdomyolysis and polysaccharide storage myopathy in horses. Comp Cont Educ 19: 1077-1084

VALENTINE BA 2003: Equine polysaccharide storage myopathy. Equine Vet Educ 15: 254-262

VALENTINE BA, MCDONOUGH SP, CHANG YF 1997: Muscle glykogen, myopathy, and diet. World Equine Vet Rev 2: 27-31

VALENTINE BA, HINTZ HF, FREELS KM, REYNOLDS AJ, THOMPSON KN 1998: Dietary control of exertional rhabdomyolysis in horses. JAVMA 212:1588-1593

VALENTINE BA, VANSAUN RJ, THOMPSON KN, HINTZ HF 2001: Role of dietary carbohydrate and fat in horses with equine polysaccharide storage myopathy. JAVMA 219: 1537-1543

WEISS WP 1998: Requirements of fat-soluble vitamins in dairy cows: A review. J Dairy Sci 81: 2493-2501 